\title{
Genetic Relationship among Common Bean Cultivars with Enhanced Accumulation of Bioactive Compounds
}

\author{
Rigoberto Rosales-Serna ${ }^{1}$, Janet A. Gutiérrez-Uribe ${ }^{2}$, Eleazar Reyes-Barraza ${ }^{2}$, Netzahualcoyotl Mayek-Pérez ${ }^{3}$ \\ \& Sergio R. O. Serna-Saldívar ${ }^{2}$ \\ ${ }^{1}$ Instituto Nacional de Investigaciones Forestales, Agrícolas y Pecuarias, Durango, México \\ ${ }^{2}$ Centro de Biotecnología FEMSA, Tecnológico de Monterrey, Monterrey, México \\ ${ }^{3}$ Centro de Biotecnología Genómica-IPN, Reynosa, México \\ Correspondence: Rigoberto Rosales-Serna, Instituto Nacional de Investigaciones Forestales, Agrícolas y \\ Pecuarias. INIFAP-Durango. km 4.5 Carretera Durango-El Mezquital. Durango, Dgo. C. P. 34170, México. Tel: \\ E-mail: rigoberto_serna@yahoo.com
}

Received: May 31, 2015 Accepted: July 1, 2015 Online Published: August 15, 2015

doi:10.5539/jas.v7n9p106 URL: http://dx.doi.org/10.5539/jas.v7n9p106

\begin{abstract}
Common bean (Phaseolus vulgaris L.) is now considered as a nutritive food containing bioactive compounds for human health. Studies are necessary to understand genetic and environmental influence over yield and the accumulation of bioactive compounds in seeds. Days to flowering, disease reaction, maturity, seed yield, 100 seed weight, flavonoid content and genetic relationships were evaluated in eight common bean cultivars in spring and summer cropping seasons. Flowering was registered between 36 and 54 days after planting, values between 1 and 7 were observed for CBB (Common Bacterial Blight) and maturity showed values between 88 and 98 days. Similar seed yields were registered between growing seasons and significant differences $(\mathrm{p} \leq 0.05)$ among cultivars were obtained in spring $\left(484 \mathrm{~kg} \mathrm{ha}^{-1}\right.$ to $\left.1544 \mathrm{~kg} \mathrm{ha}^{-1}\right)$ and summer $\left(1042 \mathrm{~kg} \mathrm{ha}^{-1}\right.$ to $1573 \mathrm{~kg}$ $\left.\mathrm{ha}^{-1}\right)$. Highly significant differences $(\mathrm{p} \leq 0.01)$ were observed among cultivars for myricetin, quercetin and kaempferol content. High values for seed yield and flavonoid content were observed in Negro Pacífico (1 $500 \mathrm{~kg}$ $\left.\mathrm{ha}^{-1} ; \mathrm{myr}=68.6 \mu \mathrm{g} \mathrm{g}^{-1}\right)$, Negro Nayarit $\left(1417 \mathrm{~kg} \mathrm{ha}^{-1} ; \mathrm{myr}=31.8 \mu \mathrm{g} \mathrm{g}^{-1}\right)$ and Negro Sahuatoba (1 $396 \mathrm{~kg} \mathrm{ha}^{-1}$; myr $=70.7 \mu \mathrm{g} \mathrm{g}^{-1} ;$ quer $\left.=183.5 \mu \mathrm{g} \mathrm{g}^{-1} ; \mathrm{kaemp}=7.2 \mu \mathrm{g} \mathrm{g}^{-1}\right)$. Seven SSR loci were used to establish genetic relationships among breed cultivars derived from parents collected in Southern México and Central America. Agronomic, laboratory and molecular markers allowed generating important information to find gene sources for genetic breeding programs in order to improve seed yield and bioactive compounds accumulation in common bean seeds.
\end{abstract}

Keywords: environment, flavonoids, Phaseolus vulgaris, soyasaponins, yield

\section{Introduction}

Common bean is one important component of Mexican traditional diet due to its high contents of carbohydrates, proteins, minerals and bioactive compounds which show nutraceutical properties (Guzmán-Maldonado et al., 2002; Díaz-Batalla et al., 2006; Gutiérrez-Uribe et al., 2006; Ríos-Ugalde et al., 2006; Guajardo-Flores et al., 2012, 2013). The annual per capita common bean consumption in México has been drastically reduced from 18.9 $\mathrm{kg}$ in 1996 to $11 \mathrm{~kg}$ in 2012 (Luna-Flores et al., 2012). Changes in Mexican consumer preferences have been associated to a significant reduction in daily common bean intake and an increased incidence of several human diseases such as diabetes, hypertension, obesity, myocardial infarcts and different types of cancer (Guzmán-Maldonado et al., 2002; Gutiérrez-Uribe et al., 2006; Ríos-Ugalde et al., 2006).

Several common bean cultivars showing black seed coat are being considered as an important feedstock for the elaboration of nutraceutical supplements used to improve human health (Gutiérrez-Uribe et al., 2006). Higher nutraceutical value was observed in Mesoamerican race cultivars, showing black seeds, collected in Southern México and Central America (Rosales-Serna et al., 2014). Common bean cultivars with black seeds, such as Negro 8025 (Cruz-Bravo et al., 2011) and Negro San Luis (Guajardo-Flores et al., 2012) have been successfully used for cancer control. Black seeded cultivars contain anthocyanins (Salinas-Moreno et al., 2005) and other bioactive compounds used to prevent genetic damages and cancer incidence (Oomah et al., 2005). Previous in 
vivo studies demonstrated that black bean consumption reduces cancer incidence (Hangen \& Bennink, 2002).

Forty common bean black seeded cultivars have been developed in México, showing adaptation under rainfed, residual soil moisture and irrigated systems (Rosales-Serna et al., 2004). Significant differences have been detected among cultivars for the content of anthocyanin (Salinas-Moreno et al., 2005) and flavonoids, such as myiricetin (Reyes-Barraza et al., 2013). Several compounds with nutraceutical effect have been found in Negro San Luis seeds, including myricetin, quercetin, kaempferol and several types for soyasaponins (Díaz-Batalla et al., 2006; Guajardo-Flores et al., 2012). Potential uses of different common bean cultivars have been evaluated in order to obtain raw materials for home cooking and food, as well as pharmaceutical industries. In addition, research needs to be done in order to characterize bioactive compound profiles in common bean seeds. The main objective was to evaluate genetic diversity among high yielding common bean cultivars with black seed coat and enhanced levels of bioactive compounds.

\section{Method}

\subsection{Plant Material and Agronomic Management}

Eight common bean black seeded cultivars (Table 1) were grown under irrigation conditions during the 2012 spring (March $13^{\text {th }}$ ) and summer (August $31^{\text {th }}$ ) cropping seasons, at Hualahuises, México $\left(24^{\circ} 52^{\prime} 50^{\prime \prime} \mathrm{N}\right.$, $99^{\circ} 37^{\prime} 19^{\prime \prime} \mathrm{W}$ and $371 \mathrm{~m}$ elevation). Except for Negro San Luis that belongs to the Jalisco race, the other cultivars belong to the Mesoamerican race (Singh et al., 1991). Organic fertilization was used including four commercial inoculants such as Rhizobium (Dianitro Fix-INDIAPAC Son., México), Azospirillum brasilense (Nitrox-Prodeni Mich. México), Mycorrhiza (Tec Myc 60-El Vergel México, D. F.) and Bacillus subtilis (Biotriba-Prodeni Mich., México). Prior to planting, seeds were inoculated and then dried in the shade according to manufacturer's recommendations.

Table 1. Information related to common bean black seeded germplasm evaluated at two cropping seasons in Hualahuises, México, 2012

\begin{tabular}{lllll}
\hline Cultivar & Growth Habit* & Photoperiod Response & Origin & Coat Brightness \\
\hline Negro Nayarit & II & Neutral & Nayarit & Opaque \\
Negro Tacaná & II & Neutral & Chiapas & Opaque \\
Negro Pacífico & II & Neutral & Sinaloa & Opaque \\
Negro Sahuatoba & III & Neutral & Durango & Opaque \\
Negro Altiplano & III & Neutral & Durango & Opaque \\
Frijozac N101 & III & Neutral & Zacatecas & Opaque \\
Negro San Luis & III & Sensitive & Zacatecas & Bright \\
Negro Nutra & II & Neutral & Nuevo León & Opaque \\
\hline
\end{tabular}

Note. *According to CIAT, (1984): II = Indeterminate upright; III = Indeterminate prostrated.

Soil preparation included plowing and disking, $20 \mathrm{~cm}$ raised $\times 70 \mathrm{~cm}$ width bed formation and plastic mulching with bicolor (white/black) polyethylene film. Drip irrigation system was installed using $1 / 2$ inch $(16 \mathrm{~mm})$ diameter polyethylene drip tubing, with drip emitters each $0.20 \mathrm{~m}$ and a water flow rate of $650 \mathrm{~mL} \mathrm{~h}^{-1}$ per emitter. The tube was placed along each row, following plantings and after initial irrigation two seeds were sown at each film perforation. Only one plant was left per mulch film hole and irrigation was applied during 2 to $4 \mathrm{~h}$ time periods, according to crop requirements.

\subsection{Area Description}

The predominant weather pattern in the experimental area corresponds to a warm sub-humid climate with summer-dominant rainfall, spatially annual precipitation variations from 600 to $1000 \mathrm{~mm}$ and $22.3{ }^{\circ} \mathrm{C}$ for annual average temperature (García, 1988). During both cropping cycles (spring and summer) data for maximum and minimum temperature, rainfall, and solar radiation were obtained from El Barreal, México, automatic weather station, included in the national agro-meteorological network (INIFAP, 2013), installed $8 \mathrm{~km}$ away from experiments. 


\subsection{Experimental Design}

In both cropping seasons a uniform yield trial was planted under a randomized complete block design (RCBD), with three replications during the spring and four in summer. Experimental plots consisted in one soil bed with full competence: $20 \mathrm{~m}$ in length, $0.70 \mathrm{~m}$ in width and $1.28 \mathrm{~m}$ apart. Two plant rows were sown in each bed and planting occurred in staggered double rows with plant lines $30 \mathrm{~cm}$ apart and alternate plants, spaced $33 \mathrm{~cm}$.

\subsection{Agronomic Traits}

Under field conditions days to flowering and maturity were recorded; as well as, response to plant pathogens [Common Bacterial Blight: Xanthomonas campestris = axonopodis, Bean Common Mosaic Virus (BCMV), charcoal rot (Macrophomina phaseolina) and systemic vein necrosis caused by hypersensitive reaction to BCMV]. At physiological maturity seed yield and the weight of 100 seeds were evaluated in each plot. Days to flowering were registered when more than $50 \%$ of the plants in each replication showed at least one open flower (CIAT, 1987). Disease reaction was evaluated during the grain filling period $\left(R_{8}\right)$ using the 1 to 9 scale, where 1 represents immune plants without visual symptoms and 9 related to a very susceptible cultivar. Physiological maturity was registered in each plot when most of the plants showed the typical change of color from green to yellow. In each experimental plot plant samples $\left(6.4 \mathrm{~m}^{2}\right)$ were harvested for seed yield and bioactive compounds measurement. Average seed mass was determined using subsamples of 100 seeds taken and weighed in each replication by using a digital scale with $0.1 \mathrm{~g}$ accuracy.

\subsection{Bioactive Compounds Quantification}

Extracts used for flavonoids and soyasaponins quantification were obtained according to previous research (Guajardo-Flores et al., 2012) using seed flour obtained from each field sample. Quantification was performed using an HPLC system (High Performance Liquid Chromatography), supplemented with diode array detector (DAD) and evaporative light scattering detector (ELSD) (Agilent Technologies Santa Clara, CA).

Bioactive compounds were separated using a Zorbax SB-Aq $(150 \mathrm{~mm} \times 4.6 \mathrm{~mm}$ ID, $3.5 \mu \mathrm{m}$ particle size $)$ reverse phase column (Agilent Technologies, Santa Clara, CA) and a flow of $0.5 \mathrm{~mL} \mathrm{~min}^{-1}$. Combined isocratic and gradient elution was performed with a mobile phase consisting of HPLC-grade purity ( $\mathrm{pH} 2$ ) water (Solvent A) and HPLC-grade purity acetonitrile (100\%) (Solvent B). Trifluoroacetic acid (Sigma St. Louis, MO) was used for water pH 2 adjustment. Starting with solvent B (20\%: A 80\%) an elution was performed for 6 min, then the composition was changed to $50 \%$ of $\mathrm{B}$ and $50 \%$ of A during a $12 \mathrm{~min}$ time period and finally was changed to $100 \%$ of B during $30 \mathrm{~min}$. An additional time period $(10 \mathrm{~min})$ was applied between sample readings for solvent B (100\%). Chromatograms were recorded and processed at 220, 280 and $320 \mathrm{~nm}$ and integrated using the HPAgilent Software (Chemstation 1990-2003). Absorption peak, retention time and UV spectra were used for flavonoids identification. Maximum absorption at $295 \mathrm{~nm}$ was obtained in order to confirm the detection of the DDMP (2,3-dihydro-2,5-dihydroxy-6 methyil-4H-pyran-4-one)-conjugated saponins (Guajardo-Flores et al., 2012)

\subsection{Molecular Marker Analysis}

Genetic diversity analysis was performed among cultivars using seven microsatellite loci (BM143, BM154, BM164, BM181, BM188, GATs54, GATs91) achieved from previous reported genomic sequences (Gill-Langarica et al., 2011). Amplified PCR was obtained for each SSR according to conditions reported by Gill-Langarica et al., (2011). Total reaction volume included DNA (75 ng), $0.16 \mu \mathrm{M}$ of each primer (sense and antisense), $2 \mu \mathrm{L}$ of PCR buffer 10X, 1.5-2.5 mM of Mg (depending on each primer), $2 \mathrm{mM}$ of dNTPs and $1 \mathrm{U}$ of Taq DNA polymerase. Products obtained during amplification process were purified and separated by electrophoresis using 6\% polyacrylamide gels. The Kodak Molecular Imaging System Ver. 4.0 was used for gels documentation and allele detection (Eastman Kodak, Rochester, USA).

\subsection{Statistical Analysis}

Field data were used to perform an analysis of variance using a randomized complete block design combined over environments and three (spring) to four replications (summer). Mean comparisons were computed by Tukey's honestly significant difference test (HSD, $\mathrm{p} \leq 0.05)$. For molecular markers, calculations for Euclidean distances among cultivars were performed using the NTSYS ver. 2.02e software (Rohlf, 1997) and then a dendrogram was obtained based on the UPGMA (Unweighted Pair Grouping with Arithmetic Averages) clustering method. 


\section{Results}

\subsection{Agronomic Traits}

Significant differences $(\mathrm{p} \leq 0.01)$ were obtained for the number of days to first flower and physiological maturity (Table 2). In the spring planting date, early flowering cultivars registered 44 days after planting -DAP- (Negro Tacaná, Frijozac N101 and Negro San Luis), while the late flowering cultivars were Negro Nutra (52 DAP) and Negro Sahuatoba (53 DAP). Negro San Luis was the earliest flowering cultivar during summer (36 DAP), due to its photoperiod (short days) sensitivity causing the reproductive period acceleration (Rosales-Serna et al., 2004). Late flowering cultivars during summer were Negro Sahuatoba and Negro Nutra, with 54 DAP, due to genetic background and neutral response to photoperiod, especially Negro Sahuatoba (Rosales-Serna et al., 2004).

In spring, Negro San Luis showed sensitivity to global solar radiation and high temperatures registered during the reproductive stage (Figures 1 and 2), causing pod abortion, delayed maturity ( $>105$ DAP) (Vara-Prasad et al., 2002 ) and severe yield loss. Early maturity cultivars were Negro Tacaná and Negro Pacífico (88 DAP) due to their neutral photoperiod response (Rosales-Serna et al., 2004). In summer, delayed maturity (103 DAP on average) was from 100 (Negro Nayarit, Negro Tacaná and Negro Pacífico) to 106 DAP (Negro Nutra).
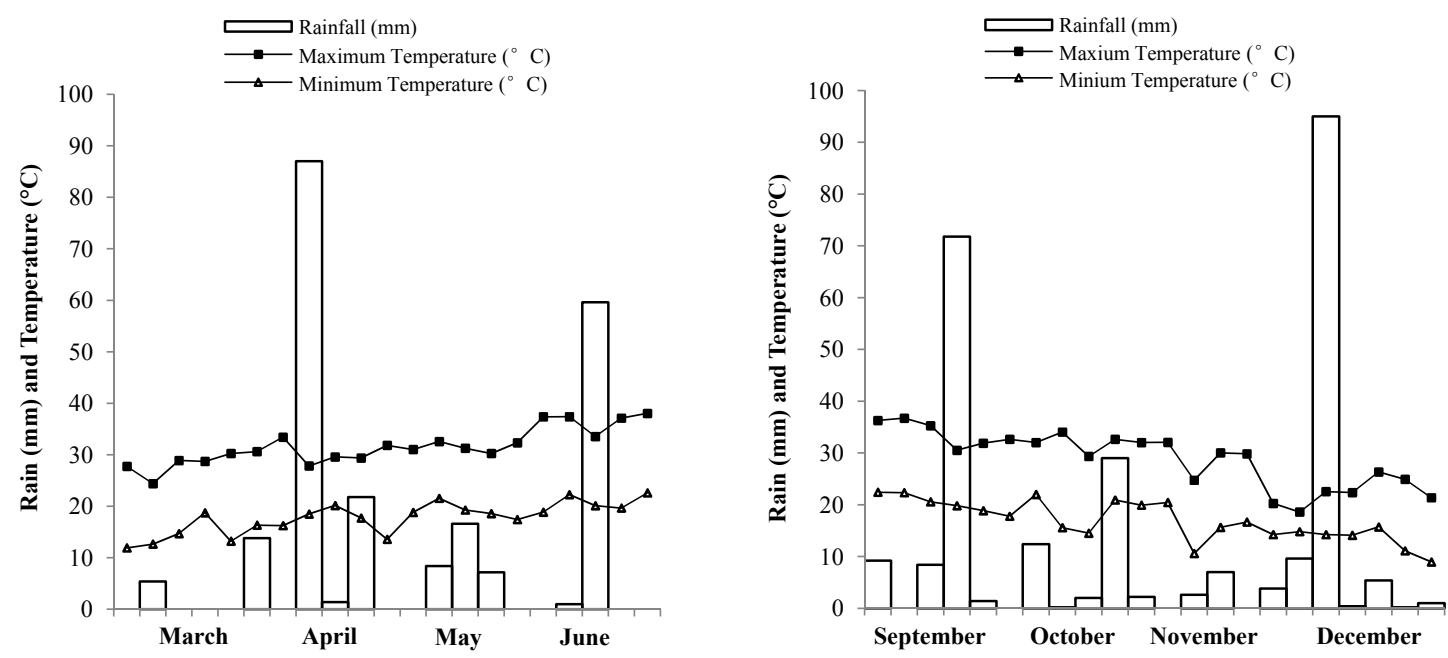

Figure 1. Accumulated rainfall and average values for maximum and minimum temperatures registered during five-day periods. Hualahuises (El Barreal), México, 2012

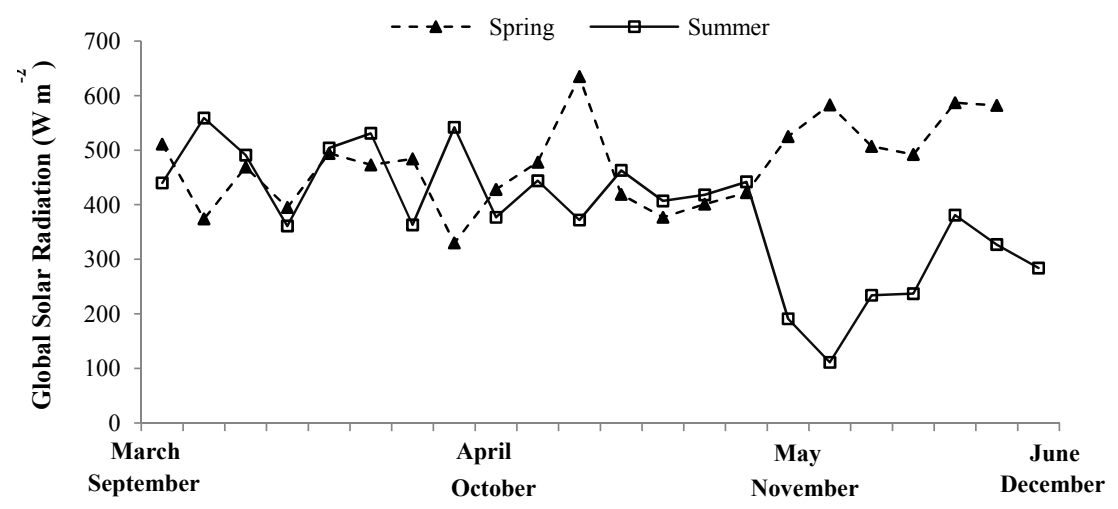

Figure 2. Average values for Global Solar Radiation $\left(\mathrm{W} \mathrm{m}^{-2}\right)$ registered in five-day periods at two cropping seasons for common bean black seeded cultivars. Hualahuises (El Barreal), México, 2012

High incidence for common bacterial blight (CBB) was registered at two cropping seasons with average values in spring from 3 (Negro Sahuatoba) to 7 (Frijozac N101); while in summer variations for score values were 
observed between 4 (Negro Nutra) and 7 (Negro San Luis) (Table 2). Compared to summer readings, spring plantings showed higher incidence for root-rot, distinguished by hypersensitive reaction to common mosaic virus (BCMV) caused by the presence of the gene $I$ (Flores-Estévez et al., 2003). Higher root-rot (BCMV) reaction value (5) was registered in Negro Tacaná, Negro Pacífico and Negro Altiplano; while Negro San Luis and Negro Nutra registered the lowest value (1). In summer plantings, high incidence of root-rot caused by Macrophomina phaseolina was observed, with values from 1 (Negro San Luis) to 4 (Negro Nayarit and Negro Nutra).

Table 2. Agronomical traits evaluated in common bean cultivars grown during spring and summer in Hualahuises, México, 2012

\begin{tabular}{|c|c|c|c|c|c|c|}
\hline Cultivar & Days to Flowering & CBB* & $\mathrm{RR}$ & Days to Maturity & Seed Yield $\left(\mathrm{kg} \mathrm{ha}^{-1}\right)$ & 100 Seed Weight $(\mathrm{g})$ \\
\hline & \multicolumn{6}{|c|}{ Spring } \\
\hline Nayarit & $49^{\mathrm{b}}$ & 4 & 4 & $90^{\mathrm{ab}}$ & $1351^{\mathrm{ab}}$ & $14^{\mathrm{b}}$ \\
\hline Tacaná & $44^{\mathrm{c}}$ & 5 & 5 & $88^{\mathrm{b}}$ & $1544^{\mathrm{a}}$ & $16^{\mathrm{b}}$ \\
\hline Pacífico & $46^{\mathrm{c}}$ & 5 & 5 & $88^{\mathrm{b}}$ & $1539^{\mathrm{a}}$ & $16^{\mathrm{b}}$ \\
\hline Sahuatoba & $53^{\mathrm{a}}$ & 3 & 3 & $93^{\mathrm{ab}}$ & $484^{\mathrm{b}}$ & $14^{\mathrm{b}}$ \\
\hline Altiplano & $45^{\mathrm{c}}$ & 5 & 5 & $98^{\mathrm{a}}$ & $1121^{\mathrm{ab}}$ & $21^{\mathrm{a}}$ \\
\hline Frijozac N101 & $44^{\mathrm{c}}$ & 7 & 7 & $91^{\mathrm{ab}}$ & $1117^{\mathrm{ab}}$ & $21^{\mathrm{a}}$ \\
\hline San Luis ${ }^{1}$ & 44 & 4 & 1 & 105 & -- & -- \\
\hline N. Nutra & $52^{\mathrm{a}}$ & 5 & 1 & $93^{\mathrm{ab}}$ & $1263^{a}$ & $14^{\mathrm{b}}$ \\
\hline \multirow[t]{2}{*}{ Average } & 48 & -- & -- & 92 & 1203 & 17 \\
\hline & \multicolumn{6}{|c|}{ Summer } \\
\hline Nayarit & $50^{\text {bcd }}$ & 5 & 4 & $100^{\mathrm{a}}$ & $1417^{\mathrm{a}}$ & $23^{\mathrm{c}}$ \\
\hline Tacaná & $48^{\mathrm{d}}$ & 6 & 3 & $100^{\mathrm{a}}$ & $1042^{\mathrm{a}}$ & $25^{\mathrm{bc}}$ \\
\hline Pacífico & $52^{\mathrm{ab}}$ & 5 & 3 & $100^{\mathrm{a}}$ & $1500^{\mathrm{a}}$ & $24^{\mathrm{c}}$ \\
\hline Sahuatoba & $54^{\mathrm{a}}$ & 5 & 3 & $104^{\mathrm{a}}$ & $1396^{\mathrm{a}}$ & $28^{\mathrm{b}}$ \\
\hline Altiplano & $51^{\mathrm{bc}}$ & 5 & 3 & $105^{\mathrm{a}}$ & $1438^{\mathrm{a}}$ & $33^{\mathrm{a}}$ \\
\hline Frijozac N101 & $49^{\mathrm{cd}}$ & 6 & 2 & $103^{\mathrm{a}}$ & $1573^{\mathrm{a}}$ & $35^{\mathrm{a}}$ \\
\hline San Luis ${ }^{1}$ & 36 & 7 & 1 & 102 & 1188 & 43 \\
\hline N. Nutra & $54^{\mathrm{a}}$ & 4 & 4 & $106^{\mathrm{a}}$ & $1229^{a}$ & $22^{\mathrm{c}}$ \\
\hline Average & 49 & -- & -- & 103 & 1348 & 29 \\
\hline
\end{tabular}

Note. ${ }^{*} \mathrm{CBB}=$ Common Bacterial Blight; $\mathrm{RR}=$ during spring root-rot: systemic vein necrosis caused by hypersensitive reaction to bean common mosaic virus (BCMV) and summer Charcoal Rot Macrophomina phaseolina. Disease reaction was evaluated during the grain filling period $\left(\mathrm{R}_{8}\right)$ using the 1 to 9 scale, where 1 represents immune plants without visual symptoms and 9 mean very susceptible cultivar (CIAT, 1987). ${ }^{1}$ Negro San Luis was eliminated from ANOVA, due to its delayed and undefined maturity and lack of seed yield during the spring cropping season. ${ }^{\mathrm{a}-\mathrm{d}}$ Different letters within a column indicate significant difference (Tukey's test; $\mathrm{p} \leq$ $0.05)$.

Similar values were observed for seed yield between cropping seasons and common bean cultivars (Table 2), exception was Negro Sahuatoba in spring. In the spring plantings seed yield showed variations from $484 \mathrm{~kg} \mathrm{ha}^{-1}$ (Negro Sahuatoba) to $1544 \mathrm{~kg} \mathrm{ha}^{-1}$ (Negro Tacaná). In summer plantings higher values for seed yield were registered in Frijozac N101 (1 $\left.573 \mathrm{~kg} \mathrm{ha}^{-1}\right)$ and Negro Pacífico (1 $\left.500 \mathrm{~kg} \mathrm{ha}^{-1}\right)$. Seed number and weight are important traits showing positive and direct influence on grain yield in leguminous crops (Monpara \& Gaikwad, 2014). Reduction by $41 \%$ for 100 seed weight was observed in spring plantings, showing the lowest average value (17 g per 100 seeds), while $29 \mathrm{~g}$ per 100 seeds were registered in the summer cropping season. Seed weight reduction was related to diminished grain size and then, considered as a detrimental factor for the common bean market price. However, smaller seeds usually contain higher seed coat to cotyledons ratios which 
affects amounts of phytochemical compounds mainly associated to the hull (Wang et al., 2010).

In summer, more cultivars produced very small $(<18 \mathrm{~g}$ per 100 seeds) opaque grains according to the standards of the Mexican market (Table 2). Selected cultivars included Negro Nayarit, Negro Tacaná, Negro Nutra and Negro Pacífico. The Frijozac N101 cultivar also showed high seed yield, although showed low market price due to greater grain size (35 g per 100 seeds), exceeding the standards for small grains in common beans $(<25 \mathrm{~g}$ per 100 seeds). Negro San Luis registered higher seed yield (1 $\left.188 \mathrm{~kg} \mathrm{ha}^{-1}\right)$, compared to results obtained in spring plantings, also showing quality traits required for shiny black commercial class, such as larger seeds ( $>43 \mathrm{~g}$ per 100 seeds), seed coat brightness and rounded grain shape.

\subsection{Bioactive Compounds Quantification}

The content of bioactive compounds (myricetin, quercetin and kaempferol) showed highly significant differences $(\mathrm{p} \leq 0.01)$ among cultivars (Table 3$)$. Highest average values were observed in Negro Sahuatoba for myricetin 3-O-glucoside $\left(70.7 \mu \mathrm{g} \mathrm{g}^{-1}\right)$, quercetin 4-O-galactoside $\left(183.5 \mu \mathrm{g} \mathrm{g}^{-1}\right)$ and kaempferol 3-O-glucoside $\left(7.2 \mu \mathrm{g} \mathrm{g}^{-1}\right)$. Negro Sahuatoba showed statistically similar values for myricetin 3-O-glucoside compared to Negro Pacífico, Negro Tacaná and Negro Nayarit. Similar values were also observed for quercetin 4-O-galactoside levels among Negro Sahuatoba, Negro Nutra, Frijozac N101and Negro Altiplano.

Soyasaponins Af $\left(124 \mu \mathrm{g} \mathrm{g}^{-1}\right), \mathrm{V}\left(4 \mu \mathrm{g} \mathrm{g}^{-1}\right), \alpha \mathrm{g}\left(43 \mu \mathrm{g} \mathrm{g}^{-1}\right)$ and $\beta \mathrm{g}\left(25 \mu \mathrm{g} \mathrm{g}^{-1}\right)$ showed statistically similar average values among cultivars. All the evaluated cultivars showed high average amounts for quercetin 4-O-galactoside $\left(145 \mu \mathrm{g} \mathrm{g}^{-1}\right)$ and soyasaponin Af $\left(124 \mu \mathrm{g} \mathrm{g}^{-1}\right)$ across cropping seasons. Differences were observed from previous reports (Díaz-Batalla et al., 2006), where lower average values were observed for quercetin 4-O-galactoside (10.9 $\left.\mu \mathrm{g} \mathrm{g}^{-1}\right)$, while a higher amount of kaempferol 3-O-glucoside $\left(52.3 \mu \mathrm{g} \mathrm{g}^{-1}\right)$ was registered. Results suggest that combined selection need to be applied in black seeded common bean germplasm in order to obtain higher seed yield and an increased nutraceutical value. Outstanding cultivars such as Negro Sahuatoba, Negro Pacífico and Negro Nayarit represent an important option for domestic market and nutraceutical extraction industry.

Table 3. Average bioactive compounds level $\left(\mu \mathrm{g} \mathrm{g}^{-1}\right)$ registered in several common bean cultivars grown at Hualahuises, México, during spring and summer 2012

\begin{tabular}{llllllll}
\hline Cultivar & ${ }^{1}$ Myricetin & Quercetin & Kaempferol & ${ }^{2}$ SS Af & SS V & SS $\alpha \mathrm{g}$ & SS $\beta \mathrm{g}$ \\
\hline Negro Nayarit & $* 31.8^{\mathrm{ab}}$ & $134.2^{\mathrm{bc}}$ & $1.7^{\mathrm{b}}$ & 118.4 & 3.1 & 43.5 & 24.1 \\
Negro Tacaná & $48.0^{\mathrm{ab}}$ & $107.1^{\mathrm{c}}$ & $1.7^{\mathrm{b}}$ & 111.5 & 4.3 & 36.1 & 22.3 \\
Negro Pacífico & $68.6^{\mathrm{a}}$ & $131.5^{\mathrm{bc}}$ & $1.9^{\mathrm{b}}$ & 129.1 & 5.0 & 48.6 & 27.7 \\
Negro Sahuatoba & $70.7^{\mathrm{a}}$ & $183.5^{\mathrm{a}}$ & $7.2^{\mathrm{a}}$ & 113.8 & 4.5 & 39.5 & 26.9 \\
Negro Altiplano & $28.1^{\mathrm{b}}$ & $142.8^{\mathrm{abc}}$ & $3.3^{\mathrm{b}}$ & 125.5 & 3.3 & 45.5 & 26.1 \\
Frijozac N101 & $28.6^{\mathrm{b}}$ & $155.0^{\mathrm{abc}}$ & $2.5^{\mathrm{b}}$ & 147.0 & 4.5 & 42.4 & 25.1 \\
Negro Nutra & $19.9^{\mathrm{b}}$ & $159.5^{\mathrm{ab}}$ & $2.0^{\mathrm{b}}$ & 119.7 & 3.9 & 46.8 & 25.0 \\
${ }^{3}$ Negro San Luis & $7 \pm 1$ & $116 \pm 13$ & $0.3 \pm 0.1$ & $98 \pm 19$ & $2.3 \pm 0$ & $1.7 \pm 1$ & $14 \pm 1$ \\
Average & $\mathbf{4 2 . 2}$ & $\mathbf{1 4 4 . 8}$ & $\mathbf{2 . 9}$ & $\mathbf{1 2 3 . 6}$ & $\mathbf{4 . 1}$ & $\mathbf{4 3 . 2}$ & $\mathbf{2 5 . 3}$ \\
\hline
\end{tabular}

Note. ${ }^{1}$ myricetin 3-O-glucoside; quercetin 4-O-galactoside and kaempferol 3-O-glucoside. ${ }^{2} \mathrm{SS}=\mathrm{Soyasaponin}$; ${ }^{3}$ Due to its elimination from the ANOVA only average value \pm standard error is showed. ${ }^{\mathrm{a}-\mathrm{c}}$ Different letters within a column indicate significant difference (Tukey's test; $\mathrm{p} \leq 0.05$ ). *Values were obtained as average of both cropping seasons.

Outstanding cultivars for flavonoids accumulation included in their pedigree improved lines derived from genetic recombination of old landraces and improved cultivars used in Southern México and Central America. Negro Sahuatoba included as a parent BAT 308, representing an improved line derived from Porrillo Sintético (El Salvador) and Compuesto Negro Chimaltenango (Guatemala). Negro Altiplano included as a parent Negro Jamapa cultivar released in Veracruz, México, in 1958 (Rosales-Serna et al., 2004) and referred as rich in condensed tannins, anthocyanins and flavonols with interesting biological activities (Aparicio-Fernández et al., 2008).

\subsection{Molecular Marker Analysis}

Cluster analysis grouped cultivars into two well-separated groups (Figure 3). The first group included germplasm 
where Jamapa was the common ancestor while the second showed cultivars derived from crosses among improved lines developed at CIAT's breeding program. Improved lines were derived from populations obtained crossing selected parents such as Porrillo Sintético, Compuesto Negro Chimaltenango (CNC) and germplasm collected in Central America and Southern México.

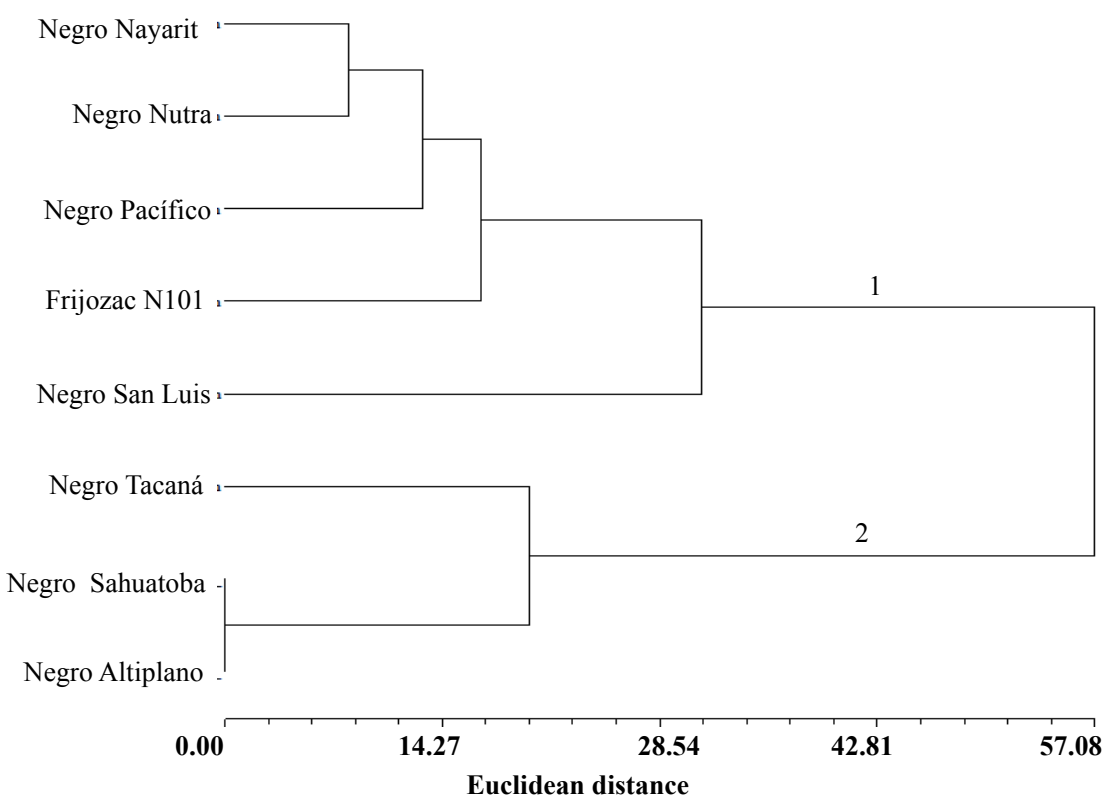

Figure 3. Genetic diversity (Euclidian distance) registered in common bean cultivars using the UPGMA clustering method

\section{Discussion}

\subsection{Agronomic Traits}

Breed cultivars as Negro Pacífico, showed high seed yield under irrigation in both spring and summer cropping seasons. Therefore it could be selected based on its neutral response to photoperiod, low hypersensitivity levels for gene $I$ to BCMV and enhanced tolerance to high temperature and global solar radiation. Summer plantings allowed a significant increase for seed weight $(41 \%)$ on average for all cultivars. This response was related to favorable temperatures for common bean growth and development registered during the grain filling period, varying from 18 to $24^{\circ} \mathrm{C}$ (Rosas et al., 2000).

Results showed the possibility for selection of some common bean cultivars in order to broaden the genetic base of common beans planted under irrigation in Northern México. Spring production obtained with some cultivars such as Negro Altiplano and Frijozac N101 showed commercial traits for traditional market (18-25 g per 100 seeds). Grains of all other cultivars that showed very small seeds ( $<18 \mathrm{~g}$ per 100 seeds) could be channeled to either the food or pharmaceutical industries, particularly Negro Sahuatoba. Better extraction of bioactive compounds is performed on small seeds, since this raw material has a greater number of seeds and seed coat proportion per kilogram of grains (Celis-Velázquez et al., 2010). Cropping season showed strong influence on yield components, reducing seed size (weight) in spring and the concomitant positive effect on seed number (per plant, pod and square meter) in order to achieve similar grain yields observed in both growing seasons.

\subsection{Bioactive Compounds Quantification}

Results suggest that temperature and global solar radiation influenced the accumulation of bioactive compounds in common bean black seeded cultivars. High temperature and radiation registered mainly during the reproductive phase caused considerable increments in flavonoids accumulation (Taleon et al., 2012). Similar results were obtained in soybean cultivars tested at different locations and planting dates (Tsukamoto et al., 1995).

Flavonoids, such as quercetin 4-O-galactoside and myricetin 3-O-glucoside were the bioactive compounds 
showing higher accumulation and variation among cultivars. Results showed differences from those reported in other studies performed in wild and cultivated common beans, where quercetin 4-O-galactoside averaged 10.9 $\mu \mathrm{g} \mathrm{g}^{-1}$ and kaempferol 3-O-glucoside $52.3 \mu \mathrm{g} \mathrm{g}^{-1}$. Differences are due to the use of more diverse common bean germplasm and variation of climatic characteristics where the seeds were produced. Flavonoids content were lower than those observed in previous studies including myricetin 3-O-glucoside $\left(115.7 \mu \mathrm{g} \mathrm{g}^{-1}\right)$ and quercetin 4-O-galactoside (643.2 $\mu \mathrm{g} \mathrm{g}^{-1}$ ) (Guajardo-Flores et al., 2012) mainly due to differences in seed source and crop management.

Higher soyasaponin concentration, particularly SSAf and SSag, was related to high temperatures registered during seed development mainly in the spring planting date. Similar results were obtained in studies performed in soybeans (Tsukamoto et al., 1995). Variations observed for bioactive compounds accumulation and their interactions with some climatic factors showed the need to optimize the gene-environment interaction in order to enhance concentration of a specific plant molecule. Cultivars showing high content for a specific and bioactive compound were selected in spite of total flavonoids content. Cultivars with high yields of seed and bioactive compounds were also identified, such as Negro Pacífico and Negro Nayarit. Negro Sahuatoba showed high values for most bioactive compounds but low seed yield in spring plantings. Negro Nutra and Frijozac N101 showed high seed yield in spring and summer plantings, and the highest values for quercetin 4-O-galactoside.

Fluctuations registered for the content of bioactive compounds was due to the high temperatures and incidence of global radiation mainly during the reproductive period. High radiation caused the need to protect plant tissues from damages caused by UV rays through the accumulation of protective pigments (Beggs et al., 1985) in leaves and stems. Protective pigments are then transported during photoassimilate translocation from leaves to pods and seeds. Results showed strong differences from those observed in previous reports where low effects were observed for environment (Marles et al., 2010) mainly due to lower variations in climatic and edaphic parameters observed in common bean producing areas.

Plant response by soyasaponins accumulation has also been associated with the protective effect against the incidence of pathogenic microorganisms in roots and aerial plant tissues (Iriti et al., 2009). In this case, Negro Sahuatoba showed no significant differences in the concentration of most of the phytochemicals analyzed among cropping seasons and its resistance to root-rot remained stable. On the other hand, the concentration of soyasaponin $\mathrm{V}$ was reduced along with the resistance to $\mathrm{CBB}$ registered in summer.

\subsection{Molecular Marker Analysis}

Molecular markers allowed to generate important information of the source of genes related to the accumulation of bioactive compounds in common bean seeds. Capability for bioactive compounds accumulation was associated with opaque black seeded cultivars from the Mesoamerican race. Common ancestors of most high accumulating cultivars for bioactive compounds were derived from landraces collected in México and Central América; such as, Negro Jamapa (Veracruz), Porrillo Sintético (El Salvador) and Compuesto Negro Chimaltenango (Guatemala).

\section{Conclusions}

The use of selected cultivars derived from Mesoamerican germplasm, with neutral response to photoperiod, may lead to increments in seed yield and agronomic performance among cropping seasons in irrigated common bean. Less favorable environmental conditions (high temperature) were observed in spring, resulting in lower seed weight and yield loss in some cultivars, such as Negro San Luis (Jalisco race). Variations were observed for flavonoid accumulation in seeds among cultivars. High values for temperature, global solar radiation and plant pathogen incidence during reproductive stage influenced yield and flavonoids accumulation in common bean seeds.

High values for flavonoids content were observed in breeding cultivars including parents from Mesoamerican race, such as Negro Pacífico, Frijozac N101 and Negro Sahuatoba. Results justify further studies to find landraces and improved cultivars with enhanced profiles for bioactive compounds derived from opaque black seeded cultivars from the Mesoamerican race.

Combined selection for high seed yield, commercial grain preference and content of bioactive compounds allowed the identification of highly competitive cultivars. Negro Pacífico showed acceptability for home cooking and Negro Sahuatoba was considered as an important feedstock for the nutraceutical extraction industry. Genetic diversity observed in black-seeded common bean germplasm needs to be used in order to develop improved lines with increased yield and higher nutraceutical value. 


\section{Abbreviations and Nomenclature}

$\mathrm{BCMV}=$ bean common mosaic virus; $\mathrm{CBB}=$ common bacterial blight; $\mathrm{DAD}=$ diode array detector; $\mathrm{DAP}=$ days after planting; DDMP = 2,3-dihidro-2,5 dihidroxi-6 metil-4H-pirano; ELSD = evaporative light scattering detector; HPLC = high performance liquid chromatography; HSD = honestly significant difference; $\mathrm{MeOH}=$ methanol; CNC 2 = Compuesto Negro Chimaltenango 2.

\section{Acknowledgements}

This research was supported by grants CAT-151 from Tecnológico de Monterrey - Campus Monterrey and Fondos FEMSA and Zambrano-Hellion. Dr. Rigoberto Rosales-Serna scholarship was provided by Consejo Nacional de Ciencia y Tecnología (CONACYT).

\section{References}

Aparicio-Fernández, X., Reynoso-Camacho, R., Castaño-Tostado, E., García-Gasca, T., González-de Mejía, E., Guzmán-Maldonado, S. H., ... Loarca-Piña, G. (2008). Antiradical capacity and induction of apoptosis on HeLa cells by a Phaseolus vulgaris extract. Plant Foods for Human Nutrition, 63, 35-40. Retrieved from http://link.springer.com/article/10.1007/s11130-007-0066-4

Beggs, C. J., Stolzer-Jehle, A., \& Wellmann, E. (1985). Isoflavonoid formation as an indicator of UV stress in bean (Phaseolus vulgaris L.) leaves. Plant Physiology, 79, 630-634. http://dx.doi.org/10.1104/pp.79.3.630

Celis-Velázquez, R., Peña-Valdivia, C. B., Luna-Cavazos, M., \& Aguirre, R. J. R. (2010). Caracterización morfológica de las semillas y consumo de reservas durante la emergencia de plántulas de frijol (Phaseolus vulgaris L.) silvestre y domesticado. Revista de la Facultad de Agronomía (LUZ), 27, 61-87. Retrieved from http://revfacagronluz.org.ve/PDF/enero_marzo2010/celis-velazquez.pdf

Centro Internacional de Agricultura Tropical. (1984). Morfología de la planta de frijol común (Phaseolus vulgaris L.) (2nd ed.). Cali, Colombia.

Centro Internacional de Agricultura Tropical. (1987). In A. van Shoonhoven \& M. A. Pastor-Corrales (Eds.), Sistema estándar para la evaluación de germoplasma de frijol (p. 87). Cali, Colombia.

Cruz-Bravo, R. K., Guevara-González, R., Ramos-Gómez, M., García-Gasca, T., Campos-Vega, R., Oomah, B. D., \& Loarca-Piña, G. (2011). Fermented nondigestible fraction from common bean (Phaseolus vulgaris L.) cultivar Negro 8025 modulates HT-29 cell behavior. Journal of Food Science, 76, T41-T47. http://dx.doi.org/10.1111/j.1750-3841.2010.02025.x

Díaz-Batalla, L., Widholm, J. M., Fahey, G. C. Jr., Castaño-Tostado, E., \& Paredes-López, O. (2006). Chemical components with health implications in wild and cultivated Mexican common bean seeds (Phaseolus vulgaris L.). Journal of Agricultural and Food Chemistry, 54, 2045-2052. http://dx.doi.org/10.1021/jf0517061

Flores-Estévez, N., Acosta-Gallegos, J. A., \& Silva-Rosales, L. (2003). Bean common mosaic virus and bean common mosaic necrosis virus in México. Plant Disease, 87, 2-25. http://dx.doi.org/10.1094/PDIS.2003.87.1.21

García, E. (1988). Modificaciones al sistema de clasificación climática de Köppen (Para adaptarlo a las condiciones de la República Mexicana) (4th ed.). México, D. F.: Enriqueta García de Miranda.

Gill-Langarica, H. R., Muruaga-Martínez, J. S., Vargas-Vázquez, M. L. P., Rosales-Serna, R., \& Mayek-Pérez, N. (2011). Genetic diversity analysis of common beans based on molecular markers. Genetics and Molecular Biology, 34, 595-605. http://dx.doi.org/10.1590/S1415-47572011005000056

Guajardo-Flores, D., García-Patiño, M., Serna-Guerrero, D. A., Gutiérrez-Uribe, J. A., \& Serna-Saldívar, S. R. O. (2012). Characterization and quantification of saponins and flavonoids in sprouts, seed coats and cotyledons of germinated black beans. Food Chemistry, 134, 1312-1319. http://dx.doi.org/10.1016/j.foodchem.2012.03.020

Guajardo-Flores, D., Serna-Saldívar, S. R. O., \& Gutiérrez-Uribe, J. A. (2013). Evaluation of the antioxidant and antiproliferative activities of extracted saponins and flavonols from germinated black beans (Phaseolus vulgaris L.). Food Chemistry, 141, 1497-1503. http://dx.doi.org/10.1016/j.foodchem.2 013.04.010

Gutiérrez-Uribe, J. A., Serna-Saldívar, S. R. O., Moreno-Cuevas, J. E., Hernández-Brenes, C., \& Guajardo-Touché, E. M. (2006). Cancer cell growth inhibition by black bean (Phaseolus vulgaris L.) extracts [.pdf text file]. Retrieved from http://www.freepatentsonline.com/EP1750732.pdf 
Guzmán-Maldonado, S. H., Acosta-Gallegos, J. A., Álvarez-Muñoz, M. A., García-Delgado, S., \& Loarca-Piña, G. (2002). Calidad alimentaria y potencial nutracéutico del frijol (Phaseolus vulgaris L.). Agricultura Técnica en México, 28, 159-173. Retrieved from http://www.redalyc.org/articulo.oa?id=60828206

Hangen, L., \& Bennink, M. R. (2002). Consumption of black beans and, navy beans (Phaseolus vulgaris) reduced azoxymethane-induced colon cancer in rats. Nutrition and Cancer: An International Journal, 44, 60-65. http://dx.doi.org/10.1207/S15327914NC441_8

Instituto Nacional de Investigaciones Forestales, Agrícolas y Pecuarias. (2013). Agroclima. Red Nacional de Estaciones Estatales Agroclimatológicas. Retrieved from http://clima.inifap.gob.mx/redinifap/estaciones.as pxs

Iriti, M., \& Faoro, F. (2009). Chemical diversity and defense metabolism: How plants cope with pathogens and ozone pollution. International Journal of Molecular Sciences, 10, 3371-3399. http://dx.doi.org/10.3390/ijm s10083371

Luna-Flores, M., Hernández-Martínez, J., Luna-Estrada, M. G., Zelaya-de Santiago, L. H., \& García-Hernández, S. (2012). Los cultivos de frijol y maíz de grano bajo condiciones de secano en Zacatecas, México de 1980 a 2008. Revista Mexicana de Ciencias Agrícolas, 3, 327-338. Retrieved from http://revistas.inifap.gob.mx/i ndex.php/Agricolas/article/view/250/248

Marles, M. A. S., Balasubramanian, P., \& Bett, K. E. (2010). Differential accumulation of polyphenolics in black bean genotypes grown in four environments. Journal of Agricultural and Food Chemistry, 58, 7001-7006. http://dx.doi.org/10.1021/jf100630g

Monpara, B. A., \& Gaikward S. R. (2014). Combining high seed number and weight to improve seed yield potential of chickpea in India. African Crop Science Journal, 22, 1-7. Retrieved from http://www.ajol.info/index.php/acsj/article/view/101367/90557

Oomah, B. D., Cardador-Martínez, A., \& Loarca-Piña, G. (2005). Phenolics and anioxidative activities in common beans (Phaseolus vulgaris L.). Journal of the Science of Food and Agriculture, 85, 935-942. http://dx.doi.org/10.1002/jsfa.2019

Reyes-Barraza, E., Moreno-Murrieta, I., Gutiérrez-Uribe, J. A., Rosales-Serna, R., Serna-Saldívar, S. R. O., \& Serna-Guerrero, D. A. (2013). Evaluation of black seeded cultivars for yield and bioactive components in Nuevo León, México. Annual Report of the Bean Improvement Cooperative, 56, 13-14. Retrieved from http://bic.css.msu.edu/_pdf/Reports/BIC_2013_volume_56.pdf

Ríos-Ugalde, M. C., Reynoso-Camacho, R., Torres-Pacheco, I., Acosta-Gallegos, J. A., Palomino-Salinas, A. C., Ramos-Gómez, ... Guzmán-Maldonado, S. H. (2006). Effect of common bean (Phaseolus vulgaris) consumption on colon cancer in Spargue-Dawley rats. Annual Report of the Bean Improvement Cooperative, 49, 123-124. Retrieved from http://bic.css.msu.edu/_pdf/Reports/BIC_2006_volume_49.pdf

Rohlf, F. J. (1997). NTSYS-PC, Version 2.02e. Exeter.

Rosales-Serna, R., Acosta-Gallegos, J. A., Muruaga-Martínez, J. S., Hernández-Casillas, J. M., Esquivel-Esquivel, G., \& Pérez-Herrera, P. (2004). Variedades mejoradas de frijol del Instituto Nacional de Investigaciones Forestales, Agrícolas y Pecuarias. Retrieved from http://biblioteca.inifap.gob.mx:8080/jspui/handle/123456789/1818

Rosales-Serna, R., Serna-Saldívar, S. R. O., Gutiérrez-Uribe, J. A., Mayek-Pérez, N., Reyes-Barraza, E., \& Hernández-Delgado, S. (2014). Genetic relationships among black-seeded common bean cultivars with different levels of bioactive compounds. Annual Report of the Bean Improvement Cooperative, 57, 193-194. Retrieved from http://bic.css.msu.edu/_pdf/Reports/BIC_2014_volume_57.pdf

Rosas, J. C., Castro, A., Beaver, J. S., Pérez, C. A., Morales, A., \& Lépiz, R. (2000). Mejoramiento genético para tolerancia a altas temperaturas y resistencia a mosaico dorado en frijol común. Agronomía Mesoamericana, 11, 1-10. http://dx.doi.org/10.15517/am.v11i1.17327

Salinas-Moreno, Y., Rojas-Herrera, L., Sosa-Montes, E., \& Pérez-Herrera, P. (2005). Composición de antocianinas en variedades de frijol negro (Phaseolus vulgaris L.) cultivadas en México. Agrociencia, 39, 385-394. Retrieved from http://www.redalyc.org/articulo.oa?id=30239403

Singh, S. P., Gepts, P., \& Debouck, D. G. (1991). Races of common bean (Phaseolus vulgaris Fabaceae). Economy Botany, 45, 379-396. http://dx.doi.org/10.1007/BF02887079

Taleon, V., Dykes, L., Rooney, W. L., \& Rooney, L. W. (2012). Effect of genotype and environment on flavonoid 
concentration and profile of black sorghum grains. Journal of Cereal Science, 56, 470-475. http://dx.doi.org/10.1016/j.jcs.2012.05.001

Tsukamoto, C., Shimada, S., Igita, K., Kodou, S., Kokubun, M., Okubo, K., \& Kitamura, K. (1995). Factors affecting isoflavone content in soybean seeds: Changes in isoflavones, saponins, and composition of fatty acids at different temperatures during seed development. Journal of Agricultural and Food Chemistry, 43, 1184-1192. http://dx.doi.org/10.1021/jf00053a012

Vara-Prasad, P. V., Boote, K. J., Hartwell-Allen, L. Jr., \& Thomas, J. M. G. (2002). Effects of elevated temperature and carbon dioxide on seed-set and yield of kidney bean (Phaseolus vulgaris L.). Global Change Biology, 8, 710-721. http://dx.doi.org/10.1046/j.1365-2486.2002.00508.x

Wang, N., Hatcher, D. W., Tyler, R. T., Toews, R., \& Gawalko, E. J. (2010). Effect of cooking on the composition of beans (Phaseolus vulgaris L.) and chickpeas (Cicer arietinum L.). Food Research International, 43, 589-594. http://dx.doi.org/10.1016/j.foodres.2009.07.012

\section{Copyrights}

Copyright for this article is retained by the author(s), with first publication rights granted to the journal.

This is an open-access article distributed under the terms and conditions of the Creative Commons Attribution license (http://creativecommons.org/licenses/by/3.0/). 